Catherine S. C. Bouman

Annick A. N. M. Royakkers

Marcus J. Schultz

\section{The removal of cystatin C during continuous venovenous hemofiltration}

Accepted: 22 June 2011

Published online: 18 August 2011

(c) The Author(s) 2011. This article is published with open access at Springerlink.com

This reply refers to the comment available at: doi: 10.1007/s00134-011-2346-6.

Dear Editor,

With interest we read the paper by Kiers et al. [1] suggesting that cystatin $\mathrm{C}(\mathrm{CyC})$ is not a useful parameter for residual renal function during continuous venovenous hemofiltration (CVVH). We previously found that the sieving coefficient (SC) for the cellulose triacetate membrane for $\mathrm{CyC}$ is approximately 0.50 [2]. On the basis of the constant CyC production reported in the literature, we hypothesized that predilution $\mathrm{CVVH}$ ( $2 \mathrm{l} / \mathrm{h}$ ) is unlikely to influence serum $\mathrm{CyC}$ levels, although we did not determine changes in serum $\mathrm{CyC}$ [2]. Using the same dose $(2 \mathrm{l} / \mathrm{h}$, predilution) but a different membrane (polyacrylonitrile), Kiers et al. report a significant decrease of $\mathrm{CyC}$ after $24 \mathrm{~h}$ of CVVH in six patients with acute kidney injury (AKI). The authors do not report whether the patients were anuric during CVVH. Several factors may explain the opposite results. First, the cellulose triacetate membrane and the polyacrylonitrile membrane may behave differently in their ability to remove CyC [3]. Unfortunately, Kiers et al. did not measure $\mathrm{CyC}$ in the ultrafiltrate, and thus we are not informed on the SC. Second, it is possible that the patients in the study by Kiers et al. had recovering renal function during $\mathrm{CVVH}$, although this is not very likely. Finally, the assumption that the generation rate of $\mathrm{CyC}$ in critically ill and non-critically ill patients is comparable may be wrong. To date, only few circumstances have been identified that have an impact on the production of $\mathrm{CyC}$; nevertheless, this was never studied in critically ill patients [4]. We performed a small pilot study in six consecutive patients in order to determine the removal of $\mathrm{CyC}$ during $\mathrm{CVVH}$ and its effect on serum CyC levels. Patients were included if filter-down time was no longer than $2 \mathrm{~h}$. We applied postdilution CVVH $(35 \mathrm{ml} / \mathrm{kg} / \mathrm{h})$ and used either a polysulfone membrane (AV 600; Fresenius, Oberursel, Germany) or a cellulose triacetate membrane (UF 205; Nipro Europe, Zaventem, Belgium). Serum CyC decreased after
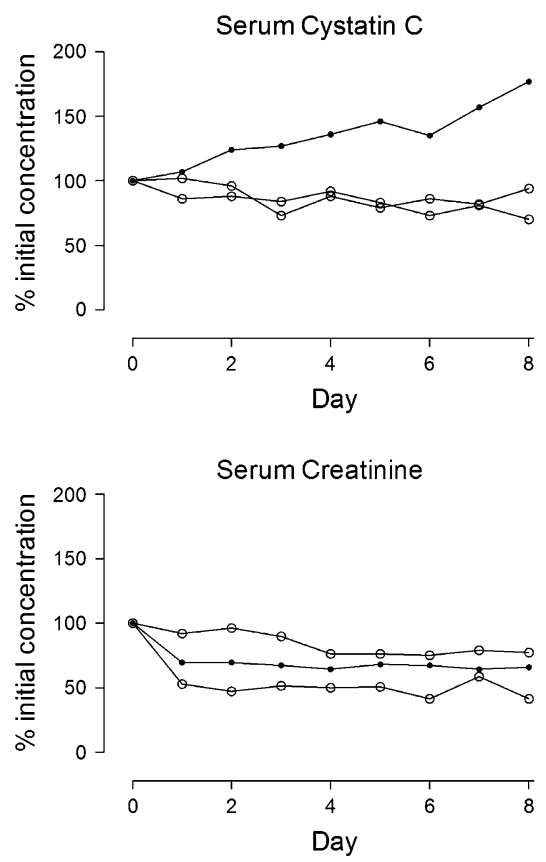

Fig. 1 Time course of serum cystatin $\mathrm{C}$ and serum creatinine during continuous venovenous hemofiltration $(\mathrm{CVVH})$. Curves represent individual patients. Open circles, cellulose triacetate membrane, closed circles polysulfone membrane. Left panel oligo-anuric patients. All patients received CVVH from day 0 until day 8. Right panel non-oliguric patients. CVVH was stopped on day 2 in two patients and on day 3 in one patient $(\perp)$

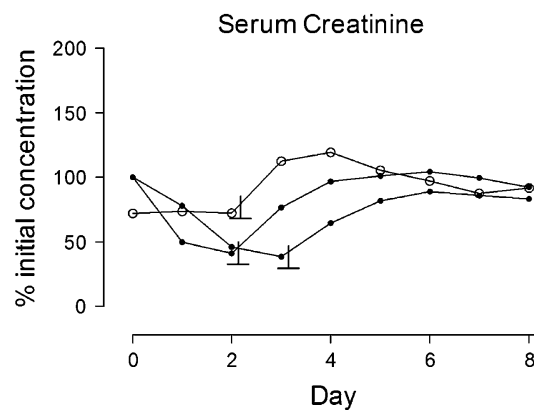
anuric and non-oliguric patients (Fig. 1). In the non-oliguric patients $\mathrm{CyC}$ levels increased after cessation of CVVH, suggesting that CVVH played an important role in the removal of CyC. When corrected for possible incomplete mixing by using the SC of urea, which should be 1 by definition, we found an SC of $0.49 \pm 0.04$ for the cellulose triacetate membrane and $0.45 \pm 12$ for the polysulfone membrane $(p=1.00)$. The CVVH dose in the present study was higher than in our earlier study and this may account for the decrease of $\mathrm{CyC}$. Another possibility is that contrary to what we proposed earlier, $\mathrm{CyC}$ production is reduced in critically ill patients. The present pilot study and the study by Kiers et al. are limited by the small number of patients. Both studies, however, reach the same conclusion suggesting that

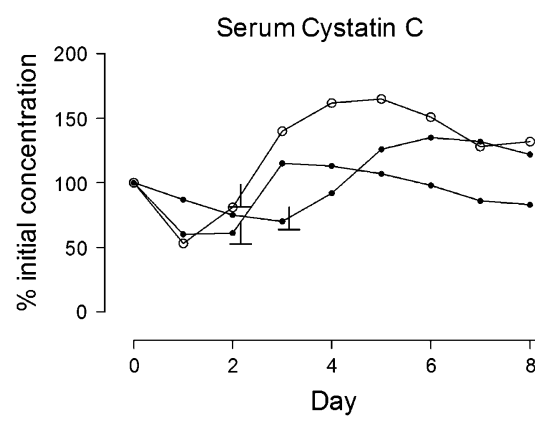

the initiation of CVVH both in oligoduring CVVH serum CyC is of little 
value in monitoring residual renal function, because $\mathrm{CVVH}$ removes $\mathrm{CyC}$ and decreases its serum levels.

Open Access This article is distributed under the terms of the Creative Commons Attribution Noncommercial License which permits any noncommercial use, distribution, and reproduction in any medium, provided the original author(s) and source are credited.

\section{References}

1. Kiers HD, de Sévaux R, Pickkers $P$ (2011) Cystatin $C$ is not a reliable marker of residual glomerular filtration rate during continuous renal replacement therapy. Intensive Care Med. doi: 10.1007/s00134-011-2346-6
2. Baas MC, Bouman CS, Hoek FJ, Krediet RT, Schultz MJ (2006) Cystatin C in critically ill patients treated with continuous venovenous hemofiltration. Hemodial Int 10:S33-S37

3. Bouman CS, van Olden RW, Stoutenbeek CP (1998) Cytokine filtration and adsorption during pre- and postdilution hemofiltration in four different membranes. Blood Purif 16:261-268

4. Filler G, Bokenkamp A, Hofmann W, Le BT, Martinez-Bru C, Grubb A (2005) Cystatin $\mathrm{C}$ as a marker of GFR-history, indications, and future research. Clin Biochem 38:1-8
C. S. C. Bouman $(\bullet) \cdot$ M. J. Schultz Department of Intensive Care, Academic Medical Center,

University of Amsterdam, P.O. Box 22660, 1100 DD Amsterdam, The Netherlands e-mail: c.s.bouman@amc.uva.nl Tel.: +31-20-5662509

A. A. N. M. Royakkers

Department of Anesthesiology,

Tergooi Hospitals, Blaricum,

The Netherlands 